\title{
Property rights, real estate markets and poverty alleviation in Namibia's urban low income settlements
}

\author{
Manya M. Mooya ${ }^{\mathrm{a}, *}$, Chris E. Cloete ${ }^{\mathrm{b}}$ \\ ${ }^{a}$ University of Cape Town, Department of Construction Economics E Management, Private Bag, Rondebosch, 7701 Cape Town, South Africa \\ ${ }^{\mathrm{b}}$ University of Pretoria, Department of Construction Economics, Pretoria 002, South Africa
}

Keywords:

Property rights

Real estate markets

Poverty alleviation

\begin{abstract}
A B S T R A C T
This paper presents part results of case study research which investigated the relationship between property rights, real estate markets and poverty alleviation in Namibia's urban low income settlements. This paper addresses the study's two central questions: first, the question of whether real estate markets in the urban informal settlements of Namibia could be used to alleviate poverty or, to put it differently, create wealth, and second, to investigate whether types of property rights matter for engendering propoor outcomes in real estate markets. The study finds that real estate is indeed a major asset held by the respondents but that there was limited secondary market activity. The study finds that, by affecting perceptions of security and investment in housing, property rights matter for capital accumulation. The study concludes that there was limited potential to derive benefits from real estate markets in aid of capital accumulation in Namibia unless interventions are made to bring about increased trading activity.

(C) 2009 Elsevier Ltd. All rights reserved.
\end{abstract}

\section{Introduction and background}

In his path-breaking The Mystery of Capital, Hernando de Soto (2000) uses the analogy of nuclear fission to emphasise the enormous latent value of real estate which could be unlocked to fight endemic poverty in developing countries, the trigger, according to him, being appropriate formal ownership regimes. The key argument in de Soto's thesis is that informal property rights in Third World countries prevent the emergence of impersonal exchange systems he sees as necessary to unlock the immense 'dead capital' locked in real estate. He advocates the formalisation of property rights as a necessary condition for fighting poverty in these countries.

Hernando de Soto's thesis is based on the fundamental assumption that the provision of individual property rights could bring about a 'triple transformation', where property is transformed into collateral, collateral into credit and credit into income (Payne, Durand-Lasserve, \& Rakodi, 2007). These ideas have provided compelling and persuasive intellectual support for the many land titling programmes going on around the world. As Payne et al. (2007) observe many international donors and national governments have over the last two decades extensively promoted

\footnotetext{
* Corresponding author. Tel.: +27 216503443.

E-mail address: manya.mooya@uct.ac.za (M.M. Mooya).
}

land titling programmes as a means of increasing tenure security, improving access to formal credit and reducing poverty.

A major problem with the de Soto thesis and programmes based on similar ideas is that they, despite their ubiquity around the world, have had limited empirical support. This leads Payne et al. (2007) to comment that despite the intellectual and financial investments made to date on land titling programmes, there was a lack of independent evidence to support or challenge the application of land titling as the most appropriate policy option to achieve the important objectives of social and economic development and reducing urban poverty. A recently completed review found no evidence of serious efforts at ex post assessments of titling programmes around the world, something that the authors describe as surprising and disturbing (Payne et al., 2007).

This paper takes as a point of departure the widely held view that formal property rights are a prerequisite for engendering propoor outcomes to interrogate the link between real estate markets and poverty. Namibia is used as a case study to answer a range of questions with broader international relevance. In common with many developing countries, the Namibian government has been promoting urban land reform of which the proposed flexible land tenure system (see below) is the central plank. According to the final draft of the Flexible Land Tenure Act, the objectives of the act are three fold (GRN, 2004). The first objective is to create alternative forms of land title that are simpler and cheaper to administer than existing forms of land title. The second objective is to provide security of title for persons who live in informal settlements or 
who are provided with low-income housing. The final objective is to empower the persons concerned economically by means of these rights.

A reading of these objectives suggests that the provision of property rights to inhabitants of informal settlements is seen as a means to the end of improving their economic welfare, a view that finds resonance in international development practice. The proposed system has been piloted in a couple of sites in the northern town of Oshakati, but the focus so far has been on technical feasibility, particularly of lowered survey standards. A number of fundamental questions remain unanswered, revolving around whether and how the flexible land tenure system, and by extension similar property-rights based approaches, can bring about poverty alleviation. Specifically, under what conditions will real estate markets bring about pro-poor outcomes? Is there a demonstrable link between property rights, real estate markets and poverty alleviation? If so what is the 'transmission mechanism'? If not, why not?

This paper presents part results of case study research which investigated the relationship between property rights, real estate markets and poverty alleviation in Namibia's low income settlements. This paper addresses the study's two central questions: firstly, the question of whether real estate markets in the urban informal settlements of Namibia could be used to alleviate poverty or, to put it differently, create wealth, and the second problem which relates to the question of whether specific forms of property rights matter for engendering pro-poor outcomes in real estate markets, and if so, what form these are likely to take. Corresponding to these questions were two working hypotheses respectively. Firstly, it is hypothesised that real estate is a significant asset held by the urban poor in Namibia and that there is potential for capital accumulation by trading-up in real estate markets. Secondly, it is hypothesised that systems of property rights affects incentives for investment in real estate, thus ultimately determining whether real estate markets may be efficacious for capital accumulation. The paper therefore interrogates the empirical basis for the claimed benefits of titling programmes, and seeks to clarify conditions under which the proposed flexible land tenure system and similar innovations might work.

The paper is structured as follows. The following section describes the conceptual framework used for the study and summarises the empirical literature relevant to the study. The third section describes the methodological approach employed, followed by a presentation and discussion of results in the fourth section. Concluding comments follow thereafter in the penultimate section.

In this paper 'poverty alleviation' is used synonymously with 'capital accumulation' and 'real estate' with 'land'.

\section{Conceptual framework and literature review}

The research uses the conceptual and analytical tools provided by the New Institutional Economics (NIE), particularly theories of property rights and transaction costs. This conceptual framework is more fully described in Mooya and Cloete (2007) and will only be summarized here. Property rights in this paper refer to rights that individuals have over real estate, generally divided into three categories (Eggertsson, 1990). First, there are user rights that determine what individuals can legitimately do on their property. Secondly, there is the right to earn an income from the real estate and to engage in contracts with others for this purpose. Thirdly, there is the right to alienate or sell ownership rights over the real estate to others. Transaction cost in this paper refer to costs associated with using real estate markets and is similarly divided into three categories (after Furubotn \& Richter, 1998), namely search and information costs, bargaining and decision costs, and supervision and enforcement costs.

There is an intimate relationship between property rights and transaction costs. Barzel (1989) for instance defines transaction costs as the costs associated with the transfer, capture and protection of property rights. High transaction costs cause market failure. The conventional wisdom is that well-defined property rights lower transaction costs. Indeed, there is a widely held view that high transaction costs arising from defective formal property rights account for the underdevelopment of most developing countries, an argument which lies at the core of the de Soto thesis (Mooya \& Cloete, 2007).

Mooya and Cloete (2007) develop a conceptual framework which links informal urban real estate markets and poverty alleviation. The conceptual framework brings together institutional arrangements, property rights and transaction costs as determinants of real estate market liquidity. Market liquidity is argued as being important in the realisation of the latent value of property, which in turn helps in the accumulation of capital for the poor. Mooya and Cloete (2007: 155) argue that urban real estate markets will need the following attributes if they are to be a tool for poverty alleviation:

- Well defined, secure and enforced property rights.

- Liquidity i.e. frequent numbers of impersonal transactions.

- Low levels of uncertainty with regard to individual transactions.

- Low levels of transaction specific investment.

- Facilitative regulatory framework/institutional arrangements.

Empirical work exploring the links between property rights, real estate and poverty alleviation has in the main focussed on the impacts of land titling programmes (for detailed review of the literature see Durand-Lasserve \& Selod, 2007; Payne et al., 2007). In general this literature has tended to focus on influence of property titles on three outcomes (identified by Besley, 1995), namely on land investment, on access to credit and on real estate market development. It is fair to say that available evidence permits the making of definite conclusions in a number of respects. Firstly, with regard to the effect of title on land investment, there is some consensus that there is a positive relationship. Thus it is generally agreed that title promotes land investment and increases land values (Alston, Libecap, \& Mueller, 1999; Besley, 1995; Cantuarias \& Delgado, 2004; Deininger \& Chamorro, 2004; Durand-Lasserve \& Selod, 2007; Feder \& Feeny, 1991; Feder \& Onchan, 1987; Field, 2003; Galiani \& Schargrodsky, 2009; Kim, 2004; Lanjouw \& Levy, 2002; Payne et al., 2007; Van Gelder, 2009). Less clear is whether having title increases perceptions of tenure security (see Razzaz, 1993 and Smith, 2003 for dissenting views). It would seem however that on balance that it indeed does, especially in cases where de facto rights are perceived to be weak (Van Gelder, 2009; DurandLasserve \& Selod, 2007; Payne et al., 2007).

The evidence regarding the effect of land title on access to credit markets is a lot clearer, one might even say decisive, and generally not positive. Having legal title largely has no effect on credit markets (Gilbert, 2002; Home \& Lim, 2004; Ward, de Souza, \& Giusti, 2004; Varley, 2002, cited in Durand-Lasserve \& Selod, 2007; Galiani \& Schargrodsky, 2009; Payne et al., 2007). Finally, with regard to the effect of title on land market activity, the evidence shows that in certain contexts, formal property titles have had a positive effect on the volume of transactions (Lanjouw \& Levy, 2002; cited in Durand-Lasserve \& Selod, 2007) while in others this result has not been observed (Antwi \& Adams, 2003; Fekade, 2000; Gilbert, 2002; Kim, 2004; Ward, 2003). This is clearly an important area for empirical research, one with the aim of clarifying 
underlying socio-economic conditions under which having property title may lead to increased market activity.

Though significant progress has been made in recent years, particularly on research about the effects of property titles, significant gaps still exist in the literature (see Mooya \& Cloete, 2007). This paper contributes to the literature in a number of respects. Firstly, it attempts to operationalise a conceptual framework linking real estate markets and poverty alleviation, marking a departure from the usually idiosyncratic case studies that have hitherto characterised much research in this area. Secondly the paper sheds light on some of the unknowns regarding the functioning of urban real estate markets in Africa and other developing countries (Antwi \& Adams, 2003; Doebele, 1994; Gough \& Yankson, 2000; Kironde, 2000; Payne 1997). In this regard this paper contributes to empirical knowledge about the numerical size of the informal sector, the volumes of transactions and the general pattern of costs and prices. Finally, this paper extends the literature on the effects of property rights and demonstrates an innovative methodological approach of how this should be done.

\section{Methodology}

\section{Methodological approach}

The results discussed in this paper come from a larger case study which used the Institutional Analysis and Development (IAD) framework (after Ostrom, 2005, see Fig. 1) as a basis for the comparative analysis of the effects of three types of property rights regimes in settlements located on Windhoek's periphery, namely, freehold rights, informal rights and group rights. These property rights are conceived as the key institutional variable differentially affecting their respective markets. Freehold property rights are clearly defined, both in terms of content and spatial extent. This means rights are held with regard to specific demarcated plots. Further, holders of these rights can sell, lease bequeath and exercise all the normal rights of property ownership. And very significantly, these rights are enforceable by the state. They are therefore very secure.

The informal market on the other hand is, as the name implies, structured by informal, often illegal property rights. By informal rights we mean those rights held by economic agents that fail to adhere to the established institutional rules or are denied their protection (Portes \& Haller, 2005). Like in the formal market, property is acquired, sold, leased, given out and so on, but in an atmosphere of state disapproval. Lacking state sanction, the property rights in these markets may be weak. Indeed, residents of informal settlements may incur dispossession of property rights by way of forced evictions and relocation by the state. On the other hand, the tenuous nature of these rights may mean holders are susceptible to predatory activities of others. Hence the conventional view that informal property rights are insecure and that they therefore inhibit investment and market activity. From a policy point of view this has underpinned efforts aimed at providing formal freehold rights to residents of informal settlements. This is seen as crucial to the leveraging of, among other things, real estate markets for poverty alleviation.

Finally, the group market in the context of this study refers to those markets structured by a system of group property rights. These group rights arise from the activities of savings associations, who pool savings to purchase land from the municipality. This land is surveyed in the conventional manner, subdivided from the surrounding informal settlements and registered in freehold title in the name of a trust or other corporate body. The key difference from conventional freehold rights is that the land is occupied under a system of group tenure. Thus anything up a 100 individuals may occupy the block of land, on specific plots surveyed to a lower standard. And significantly, holders of group rights have more restricted powers to deal with their property than holders of freehold rights. For example sales to outsiders may not be allowed without the specific approval of group members.

The external boundaries and rights of group property enjoy the full protection of the state in terms of the formal law. In this sense, group rights are very secure. The internal boundaries and rights on the other hand are subject to whatever arrangements may have been agreed by members of respective groups. In most cases these would be set out in their respective constitutions. Members do not own real rights over their property i.e. they cannot for instance mortgage their land. Crucially, local groups, rather than the state, are the primary enforcement mechanism for these rights.

The case study settlements were selected on the basis that in each was present in close physical proximity the three types of property regimes. The intention was to control, up to a point, for the influence of physical and material conditions and attributes of community, thus leaving the institution of property rights as the independent or causal variable.

The comparative institutional approach adopted in this study therefore attempts to evaluate the effects of the three property rights regimes on real estate transactions. These rights systems can be conceived as occupying specific position on a continuum, moving from completely illegal to fully formalised. A comparative

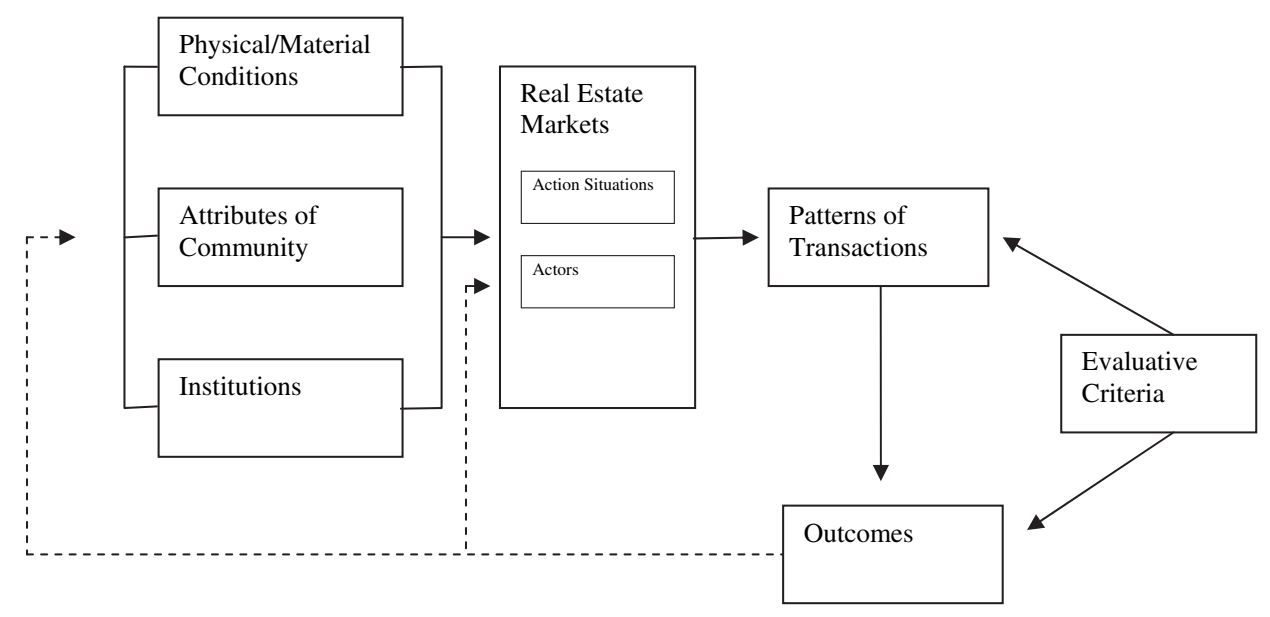

Fig. 1. A framework for real estate market analysis. Source: adapted from Ostrom, 2005: 829. 
Table 1

Numbers of households interviewed, by property rights type and settlement.

\begin{tabular}{lllll}
\hline \multirow{2}{*}{$\begin{array}{l}\text { Type of property } \\
\text { rights }\end{array}$} & \multicolumn{2}{l}{ Name of settlement } & Total \\
\cline { 3 - 4 } & & Goreangab & Okahandja Park & \\
\hline Informal & Count & 64 & 104 & 168 \\
& \% Within type & 38.1 & 61.9 & 100 \\
Group & Count & 96 & 68 & 164 \\
& \% Within type & 58.5 & 41.5 & 100 \\
Freehold & Count & 108 & 0 & 108 \\
& \% Within type & 100 & 0.0 & 100 \\
\multirow{3}{*}{ Total } & Count & 268 & 172 & 440 \\
& \% & 60.9 & 39.1 & 100 \\
\hline
\end{tabular}

assessment is clearly the best way of dealing with the vexed question of whether more formal property rights are efficacious for poverty alleviation. As Ostrom (2005) argues, without such systematic, comparative institutional assessment, recommendations on reform may be based on naïve ideas about which kinds of institutions are 'good' or 'bad' and not on the analysis of performance. This is particularly important in this case where policy interventions have in the main sought to transform informal property rights into individual freehold rights.

\section{Research instruments}

The main empirical data for the study was collected from two settlements in the north-western and northern fringes of Windhoek called Goreangab and Okahandja Park respectively. A total of 440 out of the intended 600 households were successfully interviewed. Table 1 shows the numbers of households interviewed categorised by settlement and property rights type. It is estimated that the sample represented about $10 \%$ of the relevant population though this is difficult to confirm due to the lack of suitably disaggregated data. The interviews themselves were carried out with the aid of detailed questionnaires (available on request from the author).

In addition to the standard interviews as described above, a total of 14 respondents were selected for detailed unstructured interviews with a view of getting deeper insights into aspects of the market process. Six of these were from the informal category, with four from each of the group and freehold categories. To obtain a range of contextual information, these interviews were supplemented with semi-structured interviews held with key officials from the Windhoek City Council (WCC), the Namibian Housing Action Group (NHAG), and the Namibian Housing Enterprises (NHE).

The Windhoek City Council is responsible for the control and regulation of informal settlements. Further, most of these settlements are on land that legally belongs to the municipality. The Namibian Housing Action Group (NHAG) is the service NGO to the Shack Dwellers Federation of Namibia (SDFN), an alliance of savings groups operating in many informal settlements in Namibia, whose principal aim is to mobilize collective savings for the purchase and group settlement of land for their members. The Namibian Housing Enterprises (NHE) is a state entity with a virtual monopoly in the provision of very low-income formal housing in Namibia. The NHE has a wide mandate and is therefore a significant player in this area. It acts as developer, provides loans for the purchase of its own developments and lets out units that have not been sold. Its pre-eminence in this market segment is such that all the formal housing in the Goreangab area has ultimately been developed by the NHE.

The study employed a qualitative methodology. The data was analysed mostly descriptively and the two hypotheses evaluated qualitatively. However, in order to test for significance of any differences between the three samples and to attribute these differences to respective property rights categories, three types of statistical tests were done for a few critical variables, namely:

- One way analysis of variance (ANOVA) to test for the significance of differences for continuous variables between the three samples.

- Chi-square tests to test for significance of differences between categorical variables between the three samples.

- Analysis of covariance (ANCOVA) to control for the income differences between the samples.

\section{Results and discussion}

In line with theoretical predictions the three types of property rights regimes were expected to have differential effects in their respective domains. Respondents were asked about their ability to make a range of transactions regarding their properties. Specifically they were asked about their ability to exercise the following five rights; the right to sell, the right to lease their properties, the right to run a business from their properties, the right to bequeath their properties and the right to build permanent structures. These rights lie at the core of whether and how real estate markets could be a tool for capital accumulation, and are therefore central to this paper. The right to sell and the right to rent underpin sale and rental markets and by extension the possibility to derive gains from these markets. The right to run businesses from home allows households to leverage the location of their dwellings to augment household incomes, while the right to bequeath ensures intergenerational transfer of wealth. The latter is a powerful incentive for capital accumulation by the present generation. The right to build permanent brick housing allows households to channel their savings into a tangible asset of higher value. Permanent housing is often the most visible manifestation of household wealth.

Table 2 shows the perceptions of property rights and a composite index summarising the strengths of these perceptions. The index is calculated as the sum of percentage scores as a proportion of the total possible score (i.e. 500). A score of 1 would indicate complete ability to exercise all the normal rights of ownership. In comparative terms, the strength of property rights conforms to theoretical predictions (see index column). Thus the

Table 2

Perception of property rights.

\begin{tabular}{|c|c|c|c|c|c|c|c|c|}
\hline \multirow{2}{*}{\multicolumn{2}{|c|}{$\begin{array}{l}\text { Type of property } \\
\text { rights }\end{array}$}} & \multicolumn{5}{|c|}{ Perceived right to } & \multirow[t]{2}{*}{ Rights index } & \multirow{2}{*}{$\begin{array}{l}\text { No of } \\
\text { respondents }\end{array}$} \\
\hline & & Sell & Lease & Run business & Bequeath & Build permanent & & \\
\hline Informal & $\%$ & 38.5 & 61.5 & 78.2 & 76.9 & 41.0 & 0.592 & 156 \\
\hline Group & $\%$ & 34.0 & 87.0 & 89.4 & 84.5 & 95.7 & 0.781 & 161 \\
\hline Freehold & $\%$ & 96.9 & 100.0 & 100.0 & 100 & 100.0 & 0.994 & 96 \\
\hline Total & $\%$ & 50.4 & 80.4 & 87.7 & 85.2 & 76.0 & & 413 \\
\hline
\end{tabular}


Table 3

Threats to property right.

\begin{tabular}{|c|c|c|c|c|c|c|c|}
\hline \multirow{2}{*}{\multicolumn{2}{|c|}{$\begin{array}{l}\text { Type of property } \\
\text { rights }\end{array}$}} & \multicolumn{5}{|l|}{ Type of threat } & \multirow[t]{2}{*}{ No. of respondents } \\
\hline & & Boundary encroach & Municipal eviction & Municipal relocation & Take over By others & No threat & \\
\hline Informal & \% Type & 18.2 & 57.1 & 55.8 & 6.5 & 27.3 & 154 \\
\hline Group & \% Туре & 2.5 & 25.3 & 22.8 & 0.0 & 71.4 & 158 \\
\hline Freehold & \% Type & 0.0 & 0.0 & 0.0 & 0.0 & 100.0 & 99 \\
\hline Total & $\%$ All & 7.8 & 31.1 & 29.7 & 2.4 & 61.7 & 411 \\
\hline
\end{tabular}

Table 4

Cost of building in N\$.

\begin{tabular}{|c|c|c|c|c|c|c|c|}
\hline Type of rights & Mean & Standard deviation & Maximum & Minimum & Range & Median & Number of observations \\
\hline Informal & 2542.71 & 2271.32 & $10,000.00$ & 0.00 & $10,000.00$ & 2000.00 & 130 \\
\hline Group & $10,402.37$ & $12,402.96$ & $80,000.00$ & 0.00 & $80,000.00$ & 4000.00 & 152 \\
\hline Freehold & 38500.00 & $11,502.17$ & $49,000.00$ & $28,000.0$ & $21,000.00$ & $38,500.00$ & 6 \\
\hline
\end{tabular}

more formal the category, the stronger the overall perceptions of property rights.

Overall, the data suggest that there are weaknesses regarding the strength of property rights for the informal category and to a lesser extent the group category. For the informal category the right to sell is clearly problematic, as is the right to build permanent structures. Respondents in the group category for their part appear even more constrained in their ability to sell than their informal counterparts. This is probably on account of the generalised disapproval by the SDFN of sales, especially to 'outsiders'.

Given some weaknesses in perceived property rights, it was of interest to determine what respondents believed to be the potential source of threat to those rights. The data clearly shows that eviction and relocation by the municipality are the dominant fears, in that order (Table 3 ). The municipality appears to be the single most significant source of threat to property rights in the informal settlements of Windhoek. This is followed by a fear of boundary encroachment by neighbours and, for informal respondents, a fear of dispossession by other private persons. In comparative terms, the strength of perceived threat mirrors that of strength of property rights. There are less fears of boundary encroachment by group respondents than their informal counterparts, and none of dispossession. Freeholders on the other hand have no such fears. A $100 \%$ of freeholders feel totally secure in their property holdings, compared to about $71 \%$ for the group category and only $27 \%$ in the informal category.

Theory predicts that property rights will affect the ability or willingness of households to invest in their housing. Investment in housing enhances the capital value of real estate thereby increasing the potential gains from both sale and rental markets. The data shows clear and statistically significant differences in the quality of housing between the three categories, and the evidence points to differences in property rights as the main causal factor. Differences were measured in terms of the magnitude of construction cost, house size, quality of building material used, household investment plans and perceived constraints. Table 4 shows the comparative construction costs. The differences between the rights categories are statistically significant even when the income effect is taken into account (Fig. 2). If income differences are controlled for, the average building costs for the informal category rises to $\mathrm{N} \$ 2620.44$ while those of the group and freehold categorises falls to $\mathrm{N}$ $\$ 10,183.50$ and $\mathrm{N} \$ 37,208.61$ respectively (1US\$ $=$ approx. $7 \mathrm{~N} \$$ at the date of study in April 2007).

Table 5 and Fig. 3 show that differences in average house sizes between the three categories are not statistically different. These results, though perhaps not in line with expectations, are explained by differences in the nature and degree of enforcement of property rights, as well as constraints posed by standardised house designs and lack of space. Freehold buildings must conform to municipal standards regarding maximum size, and enforcement is generally good. There is thus little room for variation in house sizes in this category, as can be seen by the relatively small standard deviation. Similarly, housing in the group category is constrained by the size of individual plots on one hand, and of the apparent need to mimic municipal building standards regarding permanent housing on the other. Respondents in the informal category have no such official restrictions, giving rise to a high standard deviation in house sizes, but the lack of space due to high densities constrains house sizes in this category.

The differences in the quality of building materials used, and by implication capital invested in the dwellings, are a lot clearer and statistically significant (Table 6 and Figs. 4 and 5). These differences are important because households have more latitude to invest in the quality of their dwellings than to increase size. Table 6 shows that informal and formal categories are at opposite ends of the scale, with the group category in the middle. The data indicates that the type of building material used is related to property rights, with proportionate more usage of permanent brick walls in the formal category. Adjusting for the income effect yields interesting results. Chi-square tests for both the lower and income groups confirm that the differences between the categories are statistically significant.

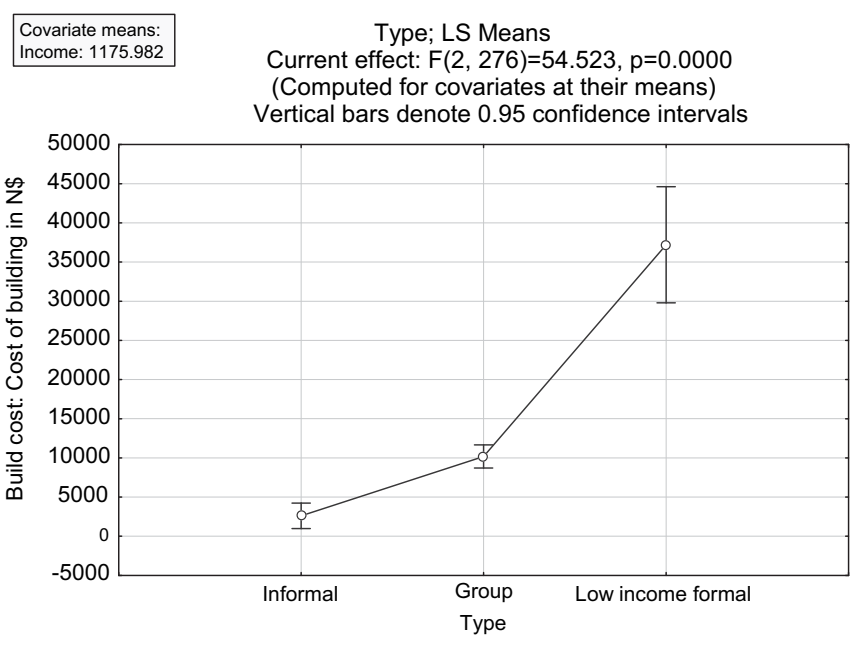

Fig. 2. Test for significance of differences in mean building cost. 
Table 5

House size (in $\mathrm{m}^{2}$ ).

\begin{tabular}{|c|c|c|c|c|c|c|c|}
\hline Type of rights & Mean & Standard deviation & Maximum & Minimum & Range & Median & Number of observations \\
\hline Informal & 31.18 & 16.19 & 78.5 & 5.8 & 72.7 & 28.75 & 168 \\
\hline Group & 30.44 & 12.99 & 72.6 & 6.3 & 66.3 & 33.00 & 157 \\
\hline Freehold & 33.63 & 11.57 & 63.1 & 7.6 & 55.5 & 27.80 & 105 \\
\hline
\end{tabular}

However, the effect of income differences is best seen in the group category where the property rights regime allows both the construction of sheet metal and brick housing. At lower income levels, a higher proportion of respondents have sheet metal housing, a picture which is reversed in the higher income group. Figs. 4 and 5 suggest that that within the overall constraints provided by the system of property rights, income differences account for much of the observed differences in housing investment.

An assessment of the respondents' future plans regarding their properties was made. The intentions were two-fold; firstly to establish the nature and likelihood of future transactions well as household investment plans and, secondly, to determine whether or not property rights were a factor in these plans. The time horizon selected was two years. The data in Table 7 shows that by far the most common intention is the physical extension or development of their houses. Households clearly want to invest in their dwellings. The main constraints, as Table 8 shows, depend to some extent on the property rights regime. Respondents in the informal group point to a lack of rights and space as the main reasons. The municipality would almost certainly notice and demolish any brick house in the informal settlement, while the huge densities make physical expansion of individual dwellings difficult. A lack of finance on the other hand is cited as the chief hindrance in the group category. Brick housing is permitted in group settlements, but requires some kind of financing for it to become reality. Finally, respondents in the freehold category cite both a lack of space and finance as principle drawbacks to house investment. The lack of space is easily explained by the fact that these households are restricted to a maximum plot size of $150 \mathrm{~m}^{2}$, leaving hardly any room for expansion. All in all therefore, appropriate property rights and financing appear to be the key factors if households have to realise their future plans.

The potential for capital accumulation in real estate markets depends on at least three key variables, the cost of property acquisition or construction, market prices of those properties and

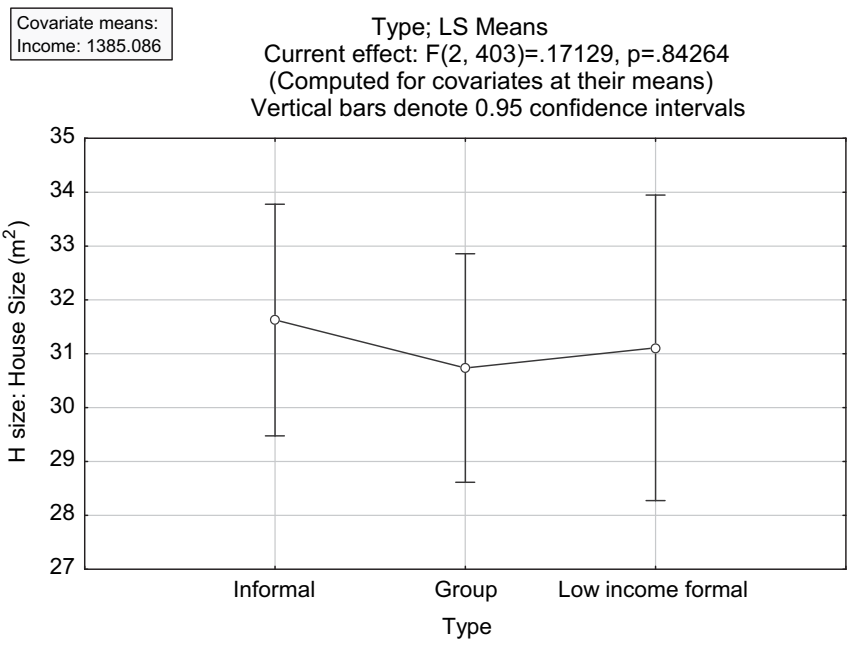

Fig. 3. Test for significance of differences in house size: income effect the existence of a market in which 'trading-up' can take place. The magnitudes of market prices and construction/acquisition costs, and their relative differences, lie at the core of whether real estate markets could be leveraged for capital accumulation. For real estate to make a difference in household poverty levels there is a requirement that sums of money changing hands, whether in the sale or rental markets be significant (or non-trivial) relative to average income levels A profitable property development market for its part requires that land and building costs be (significantly) lower than market prices.

On the surface the data shows significant differences between average estimated market prices and acquisition costs across the three categories. The latter consists of plot purchase costs (Table 9), building costs (Table 4), and, for the freehold category house, cost of purchasing complete dwellings. Average building costs (which in the absence of active markets provides the only basis for pricing, and therefore a good proxy for market value) for informal, group and freehold respondents are about $\mathrm{N} \$ 2500, \mathrm{~N} \$ 10,400$ and $\mathrm{N}$ $\$ 38,500$ respectively. The addition of plot acquisition and building costs give total average acquisition costs of about $\mathrm{N} \$ 2700$ for the informal category, $\mathrm{N} \$ 14,900$ for the group category and $\mathrm{N} \$ 56,250$ for the (minority of) freeholders who purchased plots and built their own housing. The average purchase price of a fully complete freehold housing is about $\mathrm{N} \$ 51,000$. The differences in plot acquisition costs between the rights categories are statistically significant, even when income differences are controlled for (Fig. 6).

The study was interested in comparing the costs of property acquisition with the likely proceeds arising from the disposal of properties on the 'open' market. The aim here was to assess the likely magnitudes of capital gains from market sales. Table 10 shows estimated property sale prices, as perceived by respondents. As Fig. 7 shows the differences between the rights categories are statistically significant.

Average estimated market prices are therefore about 2.3 and 1.6 times higher than acquisition costs for informal and group dwellings respectively. Average market prices for freehold property are about 1.3 times higher than average building costs and 1.5 times higher than average purchase prices. There is therefore, prima facie, potential for capital gains in the development market for all three categories. The picture in reality is a lot more complicated however. Firstly, the figures for construction costs are

Table 6

Main building material

\begin{tabular}{lllcc}
\hline \multirow{2}{*}{ Type of property rights } & \multicolumn{2}{c}{ Main building material } & \multirow{2}{*}{ Total } \\
\cline { 3 - 4 } & & Sheet metal & Brick & \\
\hline Informal & Count & 168 & 0 & 168 \\
& \% Within type & 100.0 & 0.0 & 100 \\
\multirow{3}{*}{ Group } & Count & 96 & 68 & 164 \\
& \% Within type & 58.5 & 41.5 & 100 \\
\multirow{2}{*}{ Freehold } & Count & 0 & 108 & 108 \\
& \% Within type & 0.0 & 100 & 100 \\
\multirow{3}{*}{ Total } & Count & 264 & & \\
& \% Within type & 60.0 & 176 & 440 \\
& & & 40.0 & 100 \\
\hline
\end{tabular}


Categorized Histogram: Type x Bmat

Chi-square test: $p=.00000$

Include condition: v96="<950"
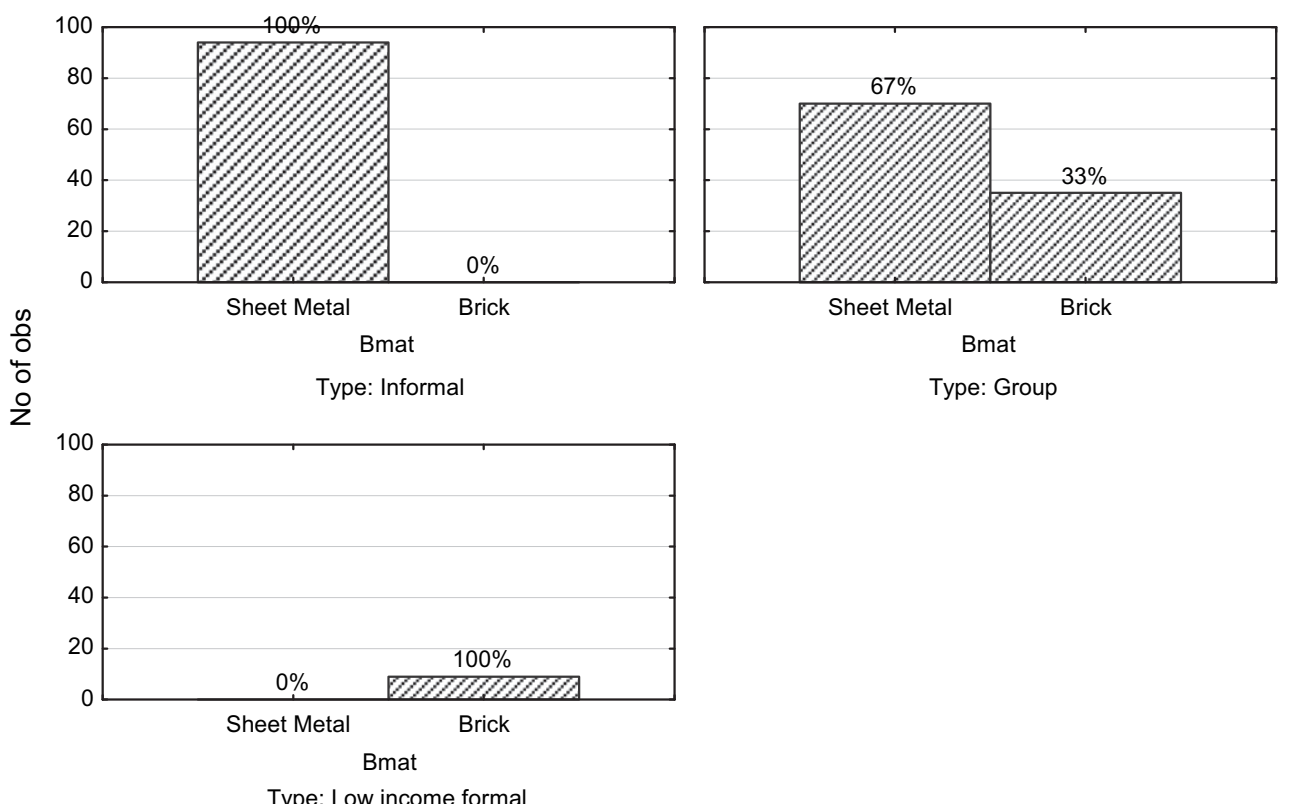

Type: Group

Fig. 4. Test for significance of differences in main building material: lower income group.

historical while estimates of market prices are based mostly on current construction costs. The lack of concurrency in time periods means that the potential for capital gains may be overstated. Secondly, the underlying value of the land is not reflected in many cases, especially in informal areas. Were underlying land value to be included, estimated market prices may well be higher, though any increases would have to be set off against increased land acquisition costs.

These complications make it difficult to make definite conclusions one way or the other about the potential for capital gains from trade in real estate. What is clearer however is the monetary value of capital tied in the real estate holdings of respondents. The

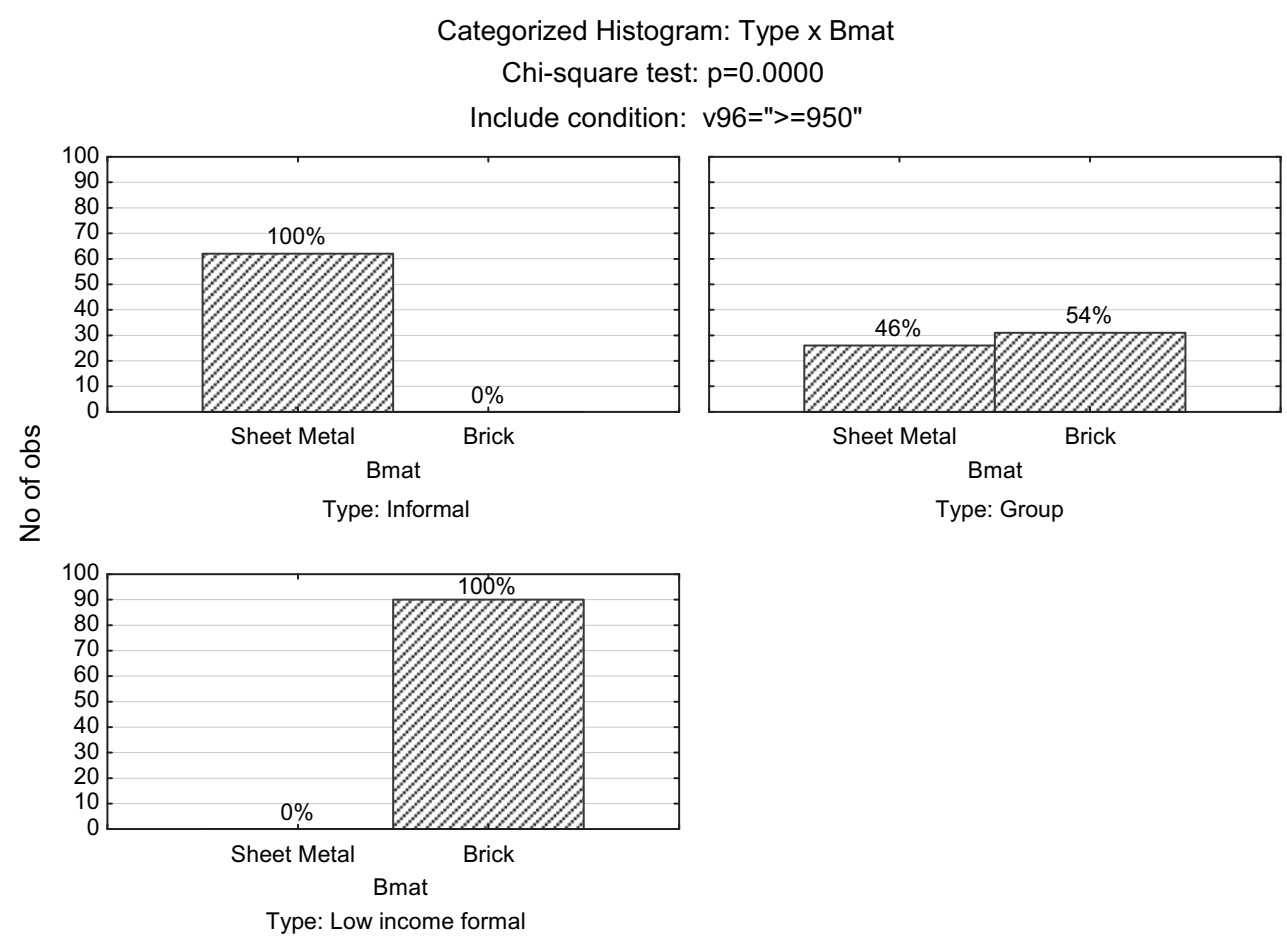

Fig. 5. Test for significance of differences in main building material: higher income group. 
Table 7

Future plans for property.

\begin{tabular}{|c|c|c|c|c|c|c|c|}
\hline \multirow{2}{*}{\multicolumn{2}{|c|}{$\begin{array}{l}\text { Type of property } \\
\text { rights }\end{array}$}} & \multicolumn{5}{|c|}{ Future plans for property } & \multirow[t]{2}{*}{ Total } \\
\hline & & $\begin{array}{l}\text { No specific } \\
\text { plan }\end{array}$ & $\begin{array}{l}\text { Sell } \\
\text { property }\end{array}$ & $\begin{array}{l}\text { Lease } \\
\text { property }\end{array}$ & $\begin{array}{l}\text { Extend } \\
\text { property }\end{array}$ & Other & \\
\hline Informal & $\begin{array}{l}\text { Count } \\
\% \\
\text { Within }\end{array}$ & $\begin{array}{l}22 \\
13.3\end{array}$ & $\begin{array}{l}0 \\
0.0\end{array}$ & $\begin{array}{l}6 \\
3.6\end{array}$ & $\begin{array}{l}82 \\
49.4\end{array}$ & $\begin{array}{l}56 \\
33.7\end{array}$ & $\begin{array}{l}166 \\
100\end{array}$ \\
\hline Group & $\begin{array}{l}\text { Count } \\
\% \\
\text { Within }\end{array}$ & $\begin{array}{l}4 \\
2.5\end{array}$ & $\begin{array}{l}0 \\
0.0\end{array}$ & $\begin{array}{l}0 \\
0.0\end{array}$ & $\begin{array}{l}112 \\
70.9\end{array}$ & $\begin{array}{l}42 \\
26.6\end{array}$ & $\begin{array}{l}158 \\
100\end{array}$ \\
\hline Freehold & $\begin{array}{l}\text { Count } \\
\% \\
\text { Within }\end{array}$ & $\begin{array}{l}0 \\
0.0\end{array}$ & $\begin{array}{l}3 \\
3.0\end{array}$ & $\begin{array}{l}3 \\
3.0\end{array}$ & $\begin{array}{l}84 \\
84.8\end{array}$ & $\begin{array}{l}9 \\
9.1\end{array}$ & $\begin{array}{r}99 \\
100\end{array}$ \\
\hline Total & $\begin{array}{l}\text { Count } \\
\% \\
\text { Within }\end{array}$ & $\begin{array}{l}26 \\
6.1\end{array}$ & $\begin{array}{l}3 \\
0.7\end{array}$ & $\begin{array}{l}9 \\
2.1\end{array}$ & $\begin{array}{l}278 \\
65.7\end{array}$ & $\begin{array}{r}107 \\
25.3\end{array}$ & $\begin{array}{l}423 \\
100\end{array}$ \\
\hline
\end{tabular}

Table 8

Constraints to future plans.

\begin{tabular}{|c|c|c|c|c|c|c|c|}
\hline \multirow{2}{*}{$\begin{array}{l}\text { Type of } \\
\text { property } \\
\text { rights }\end{array}$} & & \multicolumn{5}{|c|}{ Constraints to future plans } & \multirow{2}{*}{$\begin{array}{l}\text { No. of } \\
\text { Respondents }\end{array}$} \\
\hline & & None & $\begin{array}{l}\text { Space } \\
\text { (land) }\end{array}$ & Finance & $\begin{array}{l}\text { Not } \\
\text { allowed }\end{array}$ & Other & \\
\hline \multirow[t]{2}{*}{ Informal } & Count & 0 & 40 & 26 & 92 & 8 & 166 \\
\hline & \% Within & 0.0 & 24.1 & 15.7 & 55.4 & 4.8 & 100 \\
\hline \multirow[t]{2}{*}{ Group } & Count & 0 & 24 & 111 & 10 & 13 & 158 \\
\hline & \% Within & 0.0 & 15.2 & 70.2 & 6.3 & 8.2 & 100 \\
\hline \multirow[t]{2}{*}{ Freehold } & Count & 0 & 20 & 59 & 17 & 3 & 99 \\
\hline & \% Within & 0.0 & 20.2 & 59.6 & 17.2 & 3.0 & 100 \\
\hline \multirow[t]{2}{*}{ Total } & Count & 0 & 84 & 196 & 119 & 24 & 423 \\
\hline & $\%$ All & 0.0 & 19.8 & 46.3 & 28.1 & 5.7 & 100 \\
\hline
\end{tabular}

estimated average selling prices costs are $\mathrm{N} \$ 6200, \mathrm{~N} \$ 25,000$ and $\mathrm{N}$ $\$ 76,000$ for informal, group and freehold dwellings respectively. These figures give a sense of the order of magnitudes at the lower end of residential property market. Further they show the real and statistically significant differences between these three categories and demonstrate that movement from one level to a higher one represent a big step on the property ladder. In fact the ability of real estate markets to bring about capital accumulation would be evidenced by such movement.

This brings us to the third and last key variable necessary for the leveraging of real estate markets for capital accumulation, that of the existence and frequency of trading opportunities. In the absence of official transaction data (impossible in the case of the informal and group categories and unavailable for the freehold category) the study employed indirect methods. A sense of the state of market activity in the 5 years immediately prior to the study was built by combining responses from a number of

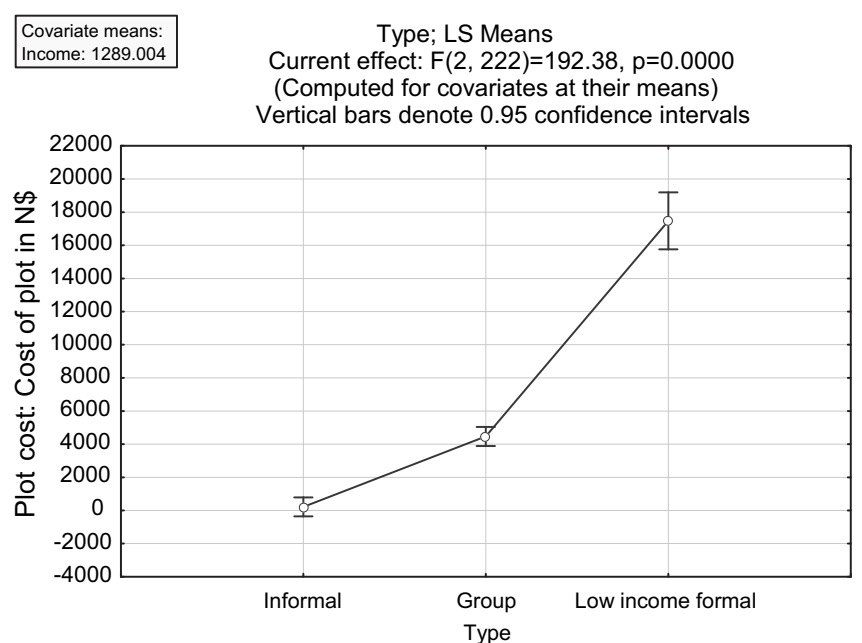

Fig. 6. Test for significance of differences in mean plot cost: income effect.

questions but principally knowledge of local sales by respondents. Bearing the relatively high densities, lack of boundary walls and close proximities between the dwellings this approach was expected to have high validity. The study has shown that there is very little secondary market activity for all three rights categories in the study area (Table 11). The data shows that over $90 \%$ of respondents in the informal category have no knowledge of any sale transaction. The respective figures for group and informal categories are $97.5 \%$ and $77.8 \%$. The finding of limited transaction activity is consistent with results obtained elsewhere (see for instance Gilbert, 2002; Home \& Lim, 2004; Ward et al., 2004). It would appear therefore that the opportunities to derive benefits from trade and expanded markets are limited in the case of Windhoek's settlements. Note however that in comparative terms there is some indication that the market for freehold rights is more active. Thus $20 \%$ of the respondents in this category are aware of at least one sale, compared to about $5 \%$ for the informal category and $1 \%$ for the group category.

Having concluded the analysis of the empirical data, it is now appropriate to evaluate the working hypotheses. It must be emphasised from the outset, and will be apparent from the analysis above, that this is a qualitative study. The data is not in a format as to yield statistical results with which to perform formal quantitative hypothesis tests. The hypotheses themselves are not framed in a manner that would permit such tests. Rather in evaluating the hypotheses, the study relies on the weight of cumulative qualitative evidence to make judgements about the extent to which they have been confirmed or rejected.

As has been pointed out, two hypotheses underpinned this study. Firstly, it was hypothesised that real estate is a significant asset held by the urban poor in Namibia and that there was potential for capital accumulation by trading-up in real estate markets. The study attempted to determine the significance of real estate assets held by respondents using a number of variables.

Table 9

Cost of plot in N\$.

\begin{tabular}{|c|c|c|c|c|c|c|c|}
\hline Type of rights & Mean & Standard deviation & Maximum & Minimum & Range & Median & Number of observations \\
\hline Informal & 160.71 & 531.75 & 3500.00 & 0.00 & 3500.00 & 0.0 & 112 \\
\hline Group & 4449.63 & 2478.13 & $12,000.00$ & 0.00 & $12,000.00$ & 5427.00 & 108 \\
\hline Freehold & $17,750.00$ & $11,087.46$ & $35,000.00$ & 6000.00 & $29,000.00$ & $15,000.00$ & 12 \\
\hline
\end{tabular}


Table 10

Estimated property sale price in $\mathrm{N} \$$.

\begin{tabular}{|c|c|c|c|c|c|c|c|}
\hline Type of rights & Mean & Standard deviation & Maximum & Minimum & Range & Median & Number of observations \\
\hline Informal & 6261.22 & 7570.84 & $30,000.00$ & 400.00 & $29,600.00$ & 3000.00 & 98 \\
\hline Group & $24,714.29$ & $21,953.90$ & $90,000.00$ & 1500.00 & $88,500.00$ & $20,000.00$ & 84 \\
\hline Freehold & $75,757.14$ & $44,504.13$ & $240,000.00$ & $24,500.00$ & $215,500.00$ & $75,000.00$ & 63 \\
\hline
\end{tabular}

These included the absolute and relative magnitudes of capital investments in dwellings and capital values. The potential for capital accumulation was measured by such variables as differences between capital values and construction costs, market transaction activity, as well as differences between capital values between the rights categories.

Results of the analysis show that on many counts real estate is indeed a significant asset held by the poor. Average construction costs and capital values are a significant proportion of average household incomes. The results show that there are considerable differences between average capital values and average construction costs. Perhaps more significantly from a capital accumulation point of view, there are significant differences between the average capital values between the rights categories. Regarding market activity, the results show that there is very limited secondary sale activity.

It is important to note that thin markets notwithstanding, the study shows that in terms of the magnitudes involved, the possibilities for capital gains are good. This is not only as a result of short run differences between cost of acquisition and sale values but long term capital appreciation arising from free or low cost initial land occupation, followed by land valorisation due to population increase, better property rights and infrastructure development. Further, the clear differences in average costs/values between the categories as well as the significant overlap between categories show that trading-up is possible. Overall the results therefore partially confirm the first hypothesis.

The second working hypothesis was that systems of property rights affects incentives for investment in real estate, thus ultimately determining whether real estate markets may be efficacious for capital accumulation. Establishing the incentive effects of property rights required comparisons of perceptions of strengthens of rights and of financial investment in dwellings. The results show that property rights do matter and that there are significant

Type; LS Means

Current effect: $F(2,242)=136.14, p=<0.01$ Kruskal-Wallis $p<0.01$ Effective hypothesis decomposition

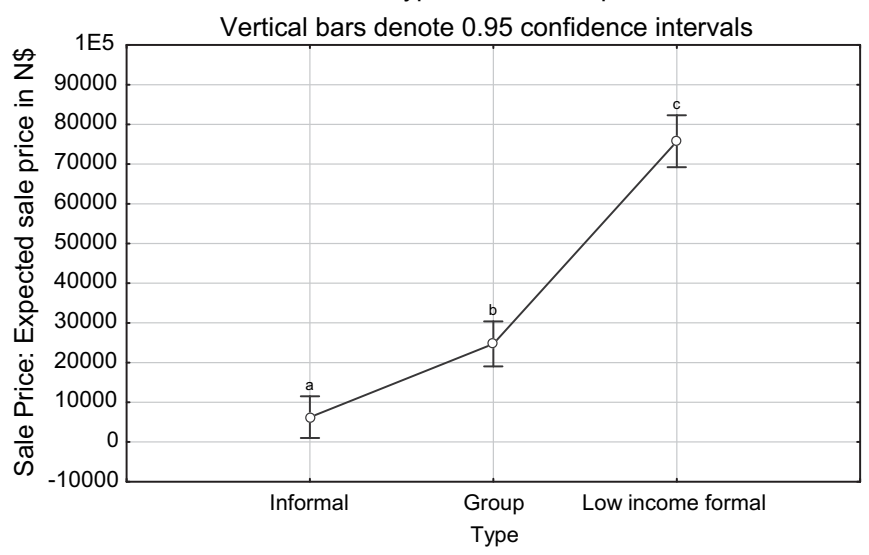

Fig. 7. Test for significance of differences in expected sale price. differences between the rights categories on the perceived strength of their respective rights. The most obvious difference between the three categories of property rights is in the quality of dwellings, reflecting differences in the amount of investment. It is quite clear that property rights matter in this regard, with the degree of formality associated with better quality housing. It must be stressed that property rights should not be seen as causing these differences completely autonomously. Other factors, such as income levels and access to finance, are important as well. However, what this case demonstrates is the power of the system of property rights to create a permissible environment in which households can invest. This is perhaps best illustrated in the group category, where the right to build permanent housing, combined with access to microfinance, allows a significant proportion of households to transform their gradual savings into substantial, good quality homes. The system of property rights therefore directly affects the ability of households to accumulate capital. It is instructive to note that the major constraint to house investment cited in the informal category is a lack of right to do so. Overall, the second hypothesis has been substantially confirmed.

The study has shown that there are some weaknesses in the quality of property rights in all categories. The informal category has, as expected, the most problems in this regard, followed by the group category. It is significant, for policy making purposes, to note that for both these categories it is the municipality, rather than private individuals, which is perceived to be the single most significant source of threat to the security of their rights. For the group category there is also confusion about whether holders of group rights can sell those rights.

As a final observation, it must be noted that while property rights matter and informal households clearly want better rights, movements up the ladder is neither automatic nor assured. Acquisition of group rights is dependent on an ability to save regularly, which may require regular income. This may be difficult for the unemployed. However evidence, from the success of the Grameen Bank in Bangladesh and this study, has shown that the poor, suitably mobilised, are able to save irrespective of their employment status. The bigger hurdle is the acquisition of freehold rights. This requires formal regular employment as collateral. This automatically rules out a big proportion of households.

Table 11

Knowledge of local sale activity

\begin{tabular}{llcllll}
\hline \multirow{2}{*}{ Type of property rights } & \multicolumn{3}{c}{ Knowledge of local sale activity } & \multirow{2}{*}{ Total } \\
\cline { 3 - 6 } & & None & 1 Person & 2 Persons & 3 Persons & \\
\hline \multirow{2}{*}{ Informal } & Count & 148 & 8 & 6 & 2 & 164 \\
& \% Within type & 90.2 & 4.9 & 3.7 & 1.2 & 100 \\
Group & Count & 156 & 2 & 2 & 0 & 160 \\
& \% Within type & 97.5 & 1.3 & 1.3 & 0.0 & 100 \\
\multirow{5}{*}{ Freehold } & Count & 84 & 21 & 0 & 3 & 108 \\
& \% Within type & 77.8 & 19.4 & 0.0 & 2.8 & 100 \\
\multirow{5}{*}{ Total } & Count & 388 & 31 & 8 & 5 & 432 \\
& \% Within type & 89.8 & 7.2 & 1.9 & 1.2 & 100 \\
\hline
\end{tabular}




\section{Concluding comments}

This paper presented results of case study research which investigated, firstly, whether real estate markets in Namibia's low income urban settlements could be an efficacious tool for poverty alleviation and, secondly, whether specific forms of property rights matter in this regard. The study has shown that a lack of secondary market activity severely limits the potential for capital gains from sale markets. This has negative implications on the ability of these markets to support trading-up, therefore inhibiting the movement of households up the property ladder. The study has however shown that there is good potential that real estate markets could be efficacious in capital accumulation. The challenge appears to lie in devising ways of priming these markets, and in the creation of appropriate institutional arrangements to support decentralised impersonal markets which allow households to invest in their dwellings. The study has demonstrated that freehold rights are associated with greater market activity but that these are inaccessible to many because of cost. Informal rights on the other hand are widely accessible to the poor but they prevent investment in housing and are associated with perceptions of insecurity. Appropriate institutional arrangements to help the poor leverage real estate markets would have to facilitate the priming of these markets allow impersonal decentralised markets to develop, and permit investment in permanent durable housing. This will require new institutional arrangements, based on the strengths of freehold rights but retaining the accessibility and flexibility advantages of informal rights. A system of group rights provides an ideal reference frame for such institutional arrangements. This study has therefore demonstrated the empirical case for innovations like the proposed flexible land tenure system which seek to introduce such types of property rights.

\section{References}

Alston, L. J., Libecap, G. D., \& Mueller, B. (1999). Titles, conflict and land use: The development of property rights on the Brazilian Amazon Frontier. Ann Arbor: Michigan University Press.

Antwi, A., \& Adams, J. (2003). Economic rationality and informal urban land transactions in Accra, Ghana. Journal of Property Research, 20(1), 67-90.

Barzel, Y. (1989). Economic analysis of property rights. Cambridge: Cambridge University Press

Besley, T. (1995). Property rights and investment incentives: theory and evidence from Ghana. Journal of Political Economy, 103(5), 903-937.

Cantuarias, F., \& Delgado, M. (2004). Peru's urban land titling program. Scaling up poverty reduction: a global learning process and conference, Shanghai, May 25-27, 2004. <http://www-wds.worldbank.org $>$. Accessed on 15.06.2009.

Deininger, K., \& Chamorro, J. (2004). Investment and equity effects of land regularisation: the case of Nicaragua. Agricultural Economics, 30, 101-116.

Doebele, W. A. (1994). Urban land and macroeconomic development. In G. Jones, \& P. M. Ward (Eds.), Methodology for land and housing market analysis. Cambridge Massachusetts: Lincoln Institute of Land Policy.

Durand-Lasserve, A., \& Selod, H. (2007). The formalisation of urban land tenure in developing countries. Paper presented to the Fourth World Bank Urban Research Symposium, 14-16 May, Washington (CD ROM).
Eggertsson, T. (1990). Economic behaviour and institutions. Cambridge: Cambridge University Press.

Feder, G., \& Feeny, D. (1991). Land tenure and property rights: theory and implications for development policy. World Bank Economic Review, 3 135-153.

Feder, G., \& Onchan, T. (1987). Land ownership security and farm investment in Thailand. American Journal of Agricultural Economics, 69, 311-320.

Fekade, W. (2000). Deficits of formal urban land management and informal responses under rapid urban growth: an international perspective. Habitat International, 24, 127-150.

Field, E. (2003). Property rights and household time allocation in urban squatter communities: evidence from Peru. Paper presented at the Second Urban Research Symposium, World Bank, Washington, DC, mimeo.

Furubotn, E. G., \& Richter, R. (1998). Institutions and economic theory: The contribution of the new institutional economics. Ann Arbor: University of Michigan Press.

Galiani, S., \& Schargrodsky, E. (2009). Property rights for the poor: effects of land titling. Working Paper No. 7, Ronald Coase Institute Working Paper Series. $<$ http://coase.org/workingpapers/wp-7.pdf >. Accessed on 15.06.2009.

Gilbert, A. G. (2002). On the mystery of capital and the myths of Hernando de Soto: what difference does legal title make? International Development Planning Review, 24(1), 1-19.

Gough, K. V., \& Yankson, P. W. K. (2000). Land markets in African cities: the case of peri-urban Accra, Ghana. Urban Studies, 37(13), 2485-2500.

GRN. (2004). Final draft of the Flexible Land Tenure Act. Windhoek: GRN.

Home, R., \& Lim, H. (2004). Demystifying the mystery of capital: Land tenure and poverty in Africa and the Caribbean. London: Glasshouse Press.

Kim, A. (2004). A market without the 'right' property rights. Economics of Transition, 12(2), 275-305.

Kironde, J. M. L. (2000). Understanding land markets in African urban areas: the case of Dar es Salaam, Tanzania. Habitat International, 24, 151-165.

Lanjouw, O. J., \& Levy, P. I. (2002). Untitled: a study of informal and formal property rights in urban Ecuador. The Economic Journal, 112, 986-1019.

Mooya, M. M., \& Cloete, C. E. (2007). Informal urban property markets and poverty alleviation: a conceptual framework. Urban Studies, 44(1), 147-165.

Ostrom, E. (2005). Doing institutional analysis: digging deeper than markets and hierarchies. In C. Menard, \& M. M. Shirley (Eds.), Handbook of new institutional economics. Dordrecht: Springer.

Payne, G. (1997). Urban land tenure and property rights in developing countries: A review. London: Intermediate Technology Publications/Overseas Development Administration (ODA).

Payne, G., Durand-Lasserve, A., \& Rakodi, C. (2007). Social and economic impacts of land titling programmes in urban and peri-urban areas: a review of the literature. Paper presented to the Fourth World Bank Urban Research Symposium, 14-16 May,. Washington (CD ROM).

Portes, A., \& Haller, W. (2005). The informal economy. In N. J. Smelser, \& R. Swedberg (Eds.), The handbook of economic sociology. Princeton, New Jersey: Princeton University Press.

Razzaz, O. M. (1993). Examining property rights and investment in informal areas: the case of Jordan. Land Economics, 69(4), 341-355.

de Soto, H. (2000). The mystery of capital: Why capitalism triumphs in the West and fails everywhere else. London: Black Swan.

Smith, R. E. (2003). Land tenure reform in Africa: a shift to the defensive. Progress in Development Studies, 3(3), 210-222.

Van Gelder, J.-L. (2009). Legal tenure security, perceived tenure security and housing improvement in Buenos Aires: an attempt towards integration. International Journal of Urban and Regional Research, 33(1), 126-146.

Varley, A. M. (2002). Private or public: debating the meaning of tenure legalisation. International Journal of Urban and Regional Research, 26(3), 449-461.

Ward, P. M. (2003). Land regularization in Latin America: lessons in the social construction of public policy. In G. A. Jones (Ed.), Urban land markets in transition. Cambridge, MA: Lincoln Institute of Land Policy (CD ROM).

Ward, P. M., de Souza, F., \& Giusti, C. (2004). 'Colonia' land and housing market performance and the impact of lot title regularisation in Texas. Urban Studies, 41 (13), 2621-2646. 